\title{
ASSOCIATION OF SEED COLOUR WITH GERMINATION, PHYSICAL AND PHYSIOLOGICAL GROWTH OF OIL PALM (Elaeis guineensis) SEEDLINGS
}

\section{G NORSAZWAN*; U R SINNIAH*; A B PUTEH*; P NAMASIVAYAM**; D R APPLETON; M MOHAIMI ${ }^{\ddagger \ddagger}$ and I A AMINUDDIN ${ }^{\ddagger \ddagger}$}

\begin{abstract}
In commercial Dura $x$ Pisifera (DxP) seed production, white-coloured seeds are perceived as abnormal despite lack of scientific evidence to support this. This study evaluates different seed colour (black, semiwhite and white) during germination and nursery evaluation. Four replications of 10 seeds were used for the evaluation of seed characteristic. Seed germination was conducted using four replications of 100 seeds by subjecting the seeds to 60 days of heat-treatment followed by germination at $30^{\circ} \mathrm{C}$. Thirty pre-germinated DxP seeds per replication were then transferred into the nursery for morphological, physiological and growth assessment at three months interval until 12 months after sowing. Germination test shows all seed types indicated similar germination percentage (more than 78\%) and speed (13-15 days of mean germination time). Nursery assessment shows black seed indicated higher overall biomass within the first three months, however, no differences in growth were observed from six until 12 months after sowing. Physiological evaluation

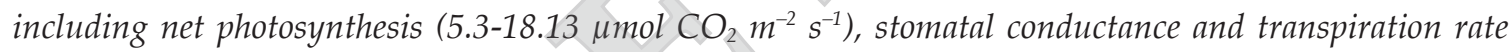
were similar among the seedlings produced by seeds differing in colour. Hence, seed colour does not implicate abnormality and should not be discarded for the purpose of seed production.
\end{abstract}

Keywords: DxP seeds, nursery management, seed colour.

Received: 28 October 2020; Accepted: 23 March 2021; Published online: 5 July 2021.

\section{INTRODUCTION}

Oil palm (Elaeis guineensis Jacq.) is known as the highest yielding oilseed in the world. On

Department of Crop Science,

Faculty of Agriculture, Universiti Putra Malaysia,

43400 Serdang, Selangor, Malaysia.

E-mail:umarani@upm.edu.my

** Department of Cell and Molecular Biology,

Faculty of Biotechnology and Biomolecular Science,

Universiti Putra Malaysia,

43400 Serdang, Selangor, Malaysia.

\# Sime Darby Technology Centre Sdn. Bhd., First Floor, Block B, UPM-MTDC Technology Centre III Malaysia, Lebuh Silikon, Putra Square, 43400 Serdang, Selangor, Malaysia.

\#‡ Sime Darby Research Sdn. Bhd., Jalan Klang Banting, Kelanang, 42700 Banting, Selangor, Malaysia. average, $4.0 \mathrm{t}$ of oil are produced per hectare of land every year, far exceeding the yield of other sources of oilseed such as soyabean, sunflower and rapeseed (Malaysian Palm Oil Council, 2018). According to the USDA (2020), total world vegetable oil consumption in 2018/2019 was 204.83 million tonnes with 74.62 million tonnes $(36.4 \%)$ being palm oil, followed by soyabean $(27.8 \%)$, rapeseed $(13.5 \%)$ and sunflower seed $(9.3 \%)$. It was estimated that oilseed consumption will exceed 240 million tonnes in 2050, based on current requirement along with population growth forecast (Corley, 2009). The increasing demand is a challenge for the oil palm industry to be more efficient particularly in ensuring higher fresh fruit bunch (FFB) yield. The main method of oil palm propagation is through seeds, using the DxP hybrid seeds. It was reported that the reduction 
of DxP seeds in Malaysia had declined from 88 million seeds in 2008 (Kushairi et al., 2010) to less than 60 million seeds per year in 2019 (Malaysian Palm Oil Board, 2020), despite the increasing forecasted demand of planting materials for 2050 (Corley, 2009). Therefore, continuous supply of pre-germinated seeds is needed for replanting and land expansion. Currently, the production of DxP pre-germinated seeds is based on a standard guideline described in Malaysian Standard MS 157: 2005 Oil Palm Seeds for Commercial Planting - Specification (Department of Standards Malaysia, 2005).

In commercial DxP seed production, white coloured seeds are often perceived as being abnormal and not favoured by the potential buyers thus, it is mainly discarded during seed production (Sime Darby Seeds and Agricultural Services, 2020). This situation leads to high monetary loss to the seed producers considering the current price of DxP seed, at RM2.35 to RM3.80 per seed. Germination parameters (final germination percentage, speed of germination and uniformity) are the focus for seed producers as it translates to saleable seeds. As for the seed buyers, the primary concern is more on the seedling performance in the nursery and after field planting. To date, despite the practice of removing the semi-white and white seeds, there is no scientific studies conducted to conclusively determine the performance of white seeds as compared with the black coloured seeds in terms of its germination, as well as seedling growth and development. Therefore, the emphasis on this study will extend beyond oil palm seed germination evaluation, by assessing the seedling performance at nursery stage prior to field planting. Various studies have shown the association between seed coat colour with both germination and seedling performance, e.g. seed colour was shown to correlate with other morphological traits such as seed coat thickness; thus, a specific colour would influence imbibition rate and germination capacity (Powell et al., 1986; Khan et al., 1997; Zhang et al., 2013; Xu et al., 2016). Seeds with higher germination percentage and vigour will allow earlier seedling establishment thus, enabling competitive advantage of the developing seedlings (Powell et al., 1986; Mohamed-Yasseen et al., 1994). Nevertheless, the capacity to germinate may not be the sole indicator of a high-quality seed. The plant resource allocation strategies have to be assessed, such as the root and shoot biomass, along with the physiological performance in the field (Padilla and Pugnaire, 2007). In commercial oil palm nursery, specific morphological characteristics of the seedlings were generally screened through standard culling practices to remove abnormal seedlings. Abnormal seedlings such as juvenile and erect seedlings have been reported to cause
$88 \%$ and $92 \%$ yield reduction within the first two years of field planting (Corley and Tinker, 2015). Despite the use of black coloured seed, the expected losses due to culling was up to $20 \%$ during the standard 12 months nursery period (Turner and Gillbanks, 2003; Corley and Tinker, 2015). In addition, seedling photosynthetic capability which encompasses the net photosynthesis and relevant parameters including transpiration rate and stomatal conductance level can be evaluated as a measure of physiological performance prior to the field planting (Ibrahim et al., 2010). Therefore, the objective of this study is to evaluate morphological and physiological performance of oil palm DxP seeds varying in colour from germination through one year of nursery stage.

\section{MATERIALS AND METHODS}

\section{Seed Collection and Pre-treatment}

Freshly harvested DxP seeds from controlled pollination of CALIX 600 Dura mother palm sources were collected from Field PT100, Sime Darby Research, Banting, Selangor, Malaysia $\left(2^{\circ} 48^{\prime} 16.2^{\prime \prime} \mathrm{N}\right.$ $\left.101^{\circ} 27^{\prime} 21.2^{\prime \prime} \mathrm{E}\right)$ : at 20 weeks after pollination. After mechanical removal of the mesocarp, the seed were treated with $0.05 \%$ Benomyl $50 \%$ wettable powder (WP) (95\% a.i) solution for $5 \mathrm{~min}$ to prevent fungal infection. The seed were then air dried at ambient temperature $\left(27.0^{\circ} \mathrm{C}-28.5^{\circ} \mathrm{C}\right)$ inside plastic containers to check for damage or mesocarp remnants.

\section{Seed Colour Distribution within Bunch and Seed Characteristics}

The distribution of seeds varying in colour was assessed according to different sections within the harvested bunch. The oil palm bunch was initially divided into three equidistance sections from the stalk, and recorded as proximal, middle and distal. Each of the sections were further divided into base and apex region of the spikelet. The number of black (endocarp surface is black or dark brown with $<10 \%$ white), semi-white (10\%-90\% endocarp surface is white) and white (endocarp surface is white, with $<10 \%$ black) seeds (Figure 1) on each position was recorded.

The seeds were then evaluated for physical characteristics. This include seed weight $(\mathrm{g})$, shell thickness $(\mathrm{mm})$, seed length and width $(\mathrm{mm})$, operculum diameter $(\mathrm{mm})$ and seed moisture content. The moisture content was also determined gravimetrically as a percentage of fresh weight basis. Seed samples were dried using low constant temperature oven method $\left(103 \pm 2^{\circ} \mathrm{C}\right.$ for $\left.17 \mathrm{hr}\right)$, following procedures described by International Seed Testing Association (2016). 


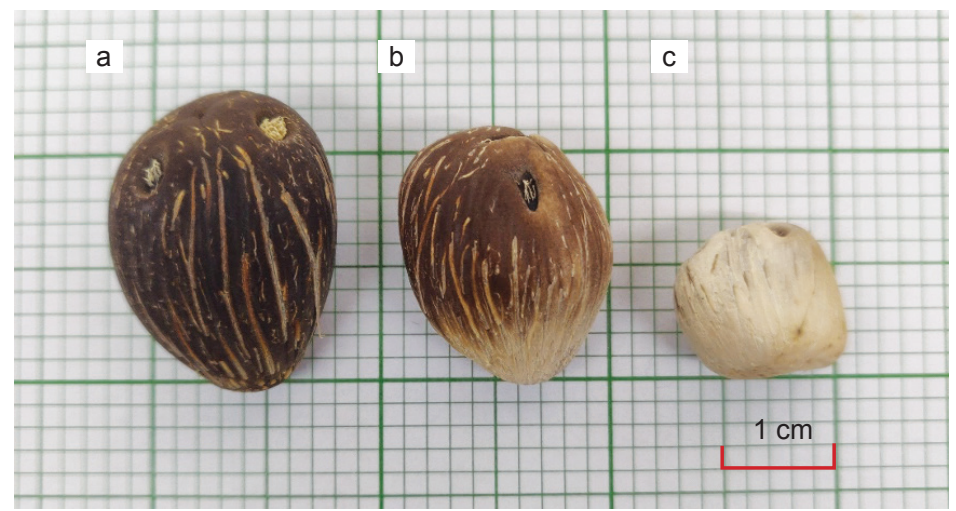

Figure 1. (a) Black, (b) semi-white, and (c) white coloured DxP seeds.

\section{Seed Germination}

Germination test. All the samples were subjected to heat treatment of $40 \pm 2{ }^{\circ} \mathrm{C}$ for 60 days. The treated seeds were than imbibed in water for 10 days before commencing germination test. Imbibed DxP seeds were separated into plastic bags containing four replicates of 100 seeds inside germination room. Germinated seeds were monitored daily by recording the number of seeds showing emergence of radicle protrusion from the fibre plug according to Sime Darby Research standard evaluation procedures. Final germination percentage (FGP), percentage of normal, abnormal, and diseased seeds, and mean germination time (MGT) were recorded.

Experimental design. The experimental design for seed germination was Randomised Complete Block Design (RCBD). The treatments (black, semi-white and white seeds) were blocked four times by using four different oil palm fruit bunch.

\section{Nursery Evaluation}

Study site and nursery preparation. The nursery assessment was conducted at Sime Darby Research pre and main nurseries in Banting, Selangor, Malaysia $\left(2^{\circ} 48^{\prime} 08.5 \mathrm{~N} 101^{\circ} 27^{\prime} 26.9 \mathrm{E}\right)$. At the prenursery stage, $6 \times 9$ inch polyethylene bags containing media (3:1 topsoil to sand) were prepared and kept under shade netting 50\% shade level throughout the three months. Each of the polybag was moistened with approximately $50 \mathrm{ml}$ of water by using automated mist-sprayer sprinkler system (10 min spraying time, two times per day). After three months, the seedlings were transferred into $15 \times 18$ inch polyethylene polybag at the main nursery site for the next nine months. Triangular spacing of $0.75 \mathrm{~m}$ were used to minimise light competition along with ease of access for fertiliser, weeding and pest control application. Prior to the transplanting, each of the polybag were filled with media (3:1 topsoil to sand) and planting holes were made using specialised core-borer. Each of the polybag were supplied with $500 \mathrm{ml}$ of water, twice per day. Nitrogen, phosphorus and potassium (NPK) 15:15:15 compound fertiliser was applied at two weeks interval with increasing rate from $5 \mathrm{~g}$ (week 16 to 20), $10 \mathrm{~g}$ (week 22 to 26) and $20 \mathrm{~g}$ (week 28 to 48). Insecticide application was also applied by alternating cypermethrin $(0.02 \%$ a.i) and dimethoate (38\% a.i) application at every two weeks interval.

Experimental design. For both pre- and main nursery evaluation, the seedlings were arranged in RCBD, where the seedlings were blocked according to sunlight direction in the field. Four replicates of 30 pre-germinated seeds from (black, semi-white, white) were sown into prepared polybags. Data was collected at 3, 6, 9 and 12 weeks after sowing. The data collection was divided into destructive (seedling growth) and non-destructive (seedling physiology) sampling methods.

Seedling growth. Four replications of three seedlings were sampled at every data collection period. Seedling height $(\mathrm{cm})$ was measured using a measuring tape. The height was taken from the base of the stem (or bole) until the end of the third fully opened leaves. Total leaf area $\left(\mathrm{cm}^{2}\right)$ was determined by using benchtop Li-COR Area Meter model LI-3100 (LI-COR, Inc., Lincoln, Nebraska, USA) at Plant Physiology Laboratory, Universiti Putra Malaysia. Both shoot and root were dried separately using oven at $70^{\circ} \mathrm{C}$ for at least $76 \mathrm{hr}$ until no change in mass was observed. The dry biomass was measured using analytical balance model B303-S (Mettler Toledo, Columbus, Ohio, USA).

Seedling physiology. Li-COR LI-6400XT Portable Photosynthesis System (LI-COR, Inc., Lincoln, Nebraska, USA) was used for physiological parameters. This include net photosynthesis ( $\mu \mathrm{mol}$ $\left.\mathrm{CO}^{2} \mathrm{~m}^{-2} \mathrm{~s}^{-1}\right)$, transpiration rate $\left(\mathrm{mmol} \mathrm{H}_{2} \mathrm{O} \mathrm{m} \mathrm{m}^{-2}\right.$ $\left.\mathrm{s}^{-1}\right)$, stomatal conductance mol $\left(\mathrm{H}_{2} \mathrm{O} \mathrm{m} \mathrm{m}^{-2} \mathrm{~s}^{-1}\right)$ and intercellular carbon dioxide $\left(\mathrm{CO}_{2}\right)$ concentration $\left(\mu \mathrm{mol} \mathrm{CO}_{2} \mathrm{~mol}^{-1}\right)$. Data collection was conducted 
between 8.00 am and 11.00 am to minimise error due to stomatal closure in the afternoon. Five data point readings were taken on the mid-section of a fully expanded leaf number three, with a total of four seedlings per treatment.

\section{Statistical Analysis}

Analysis of variance (ANOVA) was performed using Microsoft Excel and Statistical Analysis Software, SAS 9.4 (SAS Institute, Cary, North Carolina). Significant levels of $p \leq 0.05$ and $P \leq 0.01$ were applied for Least Significant Difference (LSD) test throughout this study.

\section{RESULTS}

\section{Seed Colour Distribution within a Bunch}

The ANOVA showed there was a significant effect of seed position within spikelet on percentage of black, semi-white and white seeds. Seeds that developed closer to the stalk (the base part of the spikelet), irrespective of any position within the bunch (either proximal, middle or distal) had higher percentages of white seeds in comparison to the respective apex section of the spikelet. In this study, the CALIX 600 bunches recorded an average of 2150 seeds within a bunch. At the distal section of the bunch, seeds located on the apex of the spikelet recorded 2091, 23 and 34 seeds that were categorised as black, semi-white and white, respectively. In contrast, the base region of the spikelet had 24\% (539 seeds) and 15.2\% (361 seeds) more semi-white and white seeds. Both, middle and proximal sections of the bunch indicated similar pattern as the distal (Table 1).

\section{Seed Characteristics}

The ANOVA showed that there were significant relationships of seed colour on all seed characteristics, except for seed width. White seed had significantly lower seed weight, seed length, operculum diameter and shell thickness in comparison with black, and occasionally semiwhite seeds (Table 2). White seeds were more rounded in shape (due to higher width relative to the length), in comparison with black seeds. Semi-white generally exhibited similar physical characteristics as a black seed, except with lower seed length. In terms of seed moisture content, white seeds recorded highest percentage of moisture content $(23.6 \%)$, followed by semi-white $(19.4 \%)$ and black seeds $(16.8 \%)$.

\section{Seed Germination}

No significant relationship of seed colour was recorded on all germination parameters; final germination percentage (FGP), percentage of abnormal and diseased seeds, and mean germination time (MGT). Similar FGP was recorded for black $(83.5 \%)$, semi-white seeds $(82 \%)$ and white $(79 \%)$, as shown in Table 3. Majority of the germinated seeds were classified as normal, with the mean value ranging from $78 \%$ to $82.5 \%$. Diseased and abnormal seeds were less than $2 \%$ in all treatments. All the seeds germinated within 13-15 days of MGT. Based on all other physical characteristics presented above, seeds at 20 WAP had variations in terms of the sizes, weight, along with other morphological features. However, similar level of maturity was shown based on the germination capacity.

\begin{tabular}{|c|c|c|c|c|}
\hline Position within bunch & Position within spikelet & Black & Semi-white & White \\
\hline \multirow[t]{2}{*}{ Distal } & Apex & 2091a & $23 b$ & $34 b$ \\
\hline & Base & $1249 b$ & $539 a$ & $361 \mathrm{a}$ \\
\hline \multirow[t]{2}{*}{ Middle } & Apex & $1818 \mathrm{a}$ & $238 \mathrm{ab}$ & $92 b$ \\
\hline & Base & $1337 b$ & $395 a$ & $417 a$ \\
\hline \multirow[t]{2}{*}{ Proximal } & Apex & $2072 a$ & $36 \mathrm{~b}$ & $40 \mathrm{~b}$ \\
\hline & Base & $1563 b$ & $311 a$ & $275 a$ \\
\hline Source of variation & df & & ean square $(M$ & \\
\hline Block & 3 & 2 413.98ns & $2741.40 \mathrm{~ns}$ & $2073.71 \mathrm{~ns}$ \\
\hline Seed position & 5 & $574884.92^{* *}$ & $158447.75^{\star *}$ & $130512.44^{* *}$ \\
\hline Error & 15 & 8053.43 & 7055.74 & 3814.85 \\
\hline
\end{tabular}

Note: PB - Proximal-Base; PA - Proximal-Apex; MB - Middle-Base; MA - Middle-Apex; DB - Distal-Base; DA - Distal-Apex. Different letters indicate significant differences based on LSD test at 5\% probability level; ${ }^{*}, * *$, and ns indicate significant differences at $0.05 \%, 0.01 \%$ and not significant, respectively. 
TABLE 2. DIFFERENCES IN SEED WEIGHT, SEED SIZE, OPERCULUM DIAMETER, SHELL THICKNESS AND MOISTURE CONTENT OF BLACK, SEMI-WHITE AND WHITE SEEDS

\begin{tabular}{|c|c|c|c|c|c|c|c|}
\hline Seed colour & & $\begin{array}{l}\text { Seed } \\
\text { weight } \\
\text { (g) }\end{array}$ & $\begin{array}{l}\text { Seed } \\
\text { length } \\
(\mathrm{mm})\end{array}$ & $\begin{array}{l}\text { Seed } \\
\text { width } \\
(\mathrm{mm})\end{array}$ & $\begin{array}{l}\text { Operculum } \\
\text { diameter } \\
(\mathrm{mm})\end{array}$ & $\begin{array}{c}\text { Shell } \\
\text { thickness } \\
(\mathrm{mm})\end{array}$ & $\begin{array}{c}\text { Seed moisture } \\
\text { content } \\
(\%)\end{array}$ \\
\hline Black & & $3.66 \mathrm{a}$ & $23.98 \mathrm{a}$ & $16.32 \mathrm{a}$ & $3.45 a$ & $3.06 \mathrm{a}$ & $16.80 \mathrm{~b}$ \\
\hline Semi-white & & $3.00 \mathrm{ab}$ & $16.62 b$ & $17.25 a$ & $3.43 a$ & $2.91 \mathrm{a}$ & $19.40 \mathrm{~b}$ \\
\hline White & & $2.80 \mathrm{~b}$ & $14.95 b$ & $17.74 a$ & $3.07 \mathrm{~b}$ & $2.44 \mathrm{~b}$ & $23.60 a$ \\
\hline Source of variation & df & \multicolumn{6}{|c|}{ Mean square (MS) } \\
\hline Blocks & 3 & $2.32 \mathrm{~ns}$ & $15.07 \mathrm{~ns}$ & $4.91 \mathrm{~ns}$ & $1.01 \mathrm{~ns}$ & $0.11 \mathrm{~ns}$ & \\
\hline Seed colour & 2 & $10.29^{* *}$ & $171.21^{* *}$ & $19.28 \mathrm{~ns}$ & $1.91^{*}$ & $4.17^{* *}$ & (2) 20 ** \\
\hline Error & 114 & 1.09 & 12.54 & 9.53 & 0.36 & 0.39 & \\
\hline
\end{tabular}

Note: Different letters indicate significant differences based on LSD test at $5 \%$ probability level; ${ }^{* * *}$, and ns indicate significant differences at $0.05 \%, 0.01 \%$ and not significant, respectively.

TABLE 3. FINAL GERMINATION PERCENTAGE (FGP), PERCENTAGES OF NORMAL, ABNORMAL, AND DISEASED GERMINATED SEEDS, AND MEAN GERMINATION TIME (MGT) FOR BLACK, SEMI-WHITE AND WHITE SEEDS

\begin{tabular}{|c|c|c|c|c|c|c|}
\hline Seed colour & & $\begin{array}{c}\text { FGP } \\
(\%)\end{array}$ & $\begin{array}{c}\text { Normal } \\
(\%)\end{array}$ & $\begin{array}{c}\text { Abnormal } \\
(\%)\end{array}$ & $\begin{array}{c}\text { Diseased } \\
(\%)\end{array}$ & $\begin{array}{l}\text { MGT } \\
\text { (days) }\end{array}$ \\
\hline Black & & $83.50 \mathrm{a}$ & $82.50 \mathrm{a}$ & $0.50 \mathrm{a}$ & $0.50 \mathrm{a}$ & $14.90 \mathrm{a}$ \\
\hline Semi-white & & $82.00 \mathrm{a}$ & $80.50 \mathrm{a}$ & $1.00 \mathrm{a}$ & $0.50 \mathrm{a}$ & $13.42 \mathrm{a}$ \\
\hline White & & $79.00 \mathrm{a}$ & $78.00 \mathrm{a}$ & $0.25 a$ & $0.75 a$ & $13.97 \mathrm{a}$ \\
\hline Source of variation & df & & & an square (1 & & \\
\hline Block & 3 & $168.33 \mathrm{~ns}$ & $172.89 \mathrm{~ns}$ & $0.53 \mathrm{~ns}$ & $0.33 \mathrm{~ns}$ & $6.50 \mathrm{~ns}$ \\
\hline Seed colour & 2 & $21.00 \mathrm{~ns}$ & $20.33 \mathrm{~ns}$ & $0.58 \mathrm{~ns}$ & $0.00 \mathrm{~ns}$ & $2.26 \mathrm{~ns}$ \\
\hline Error & 6 & 81.00 & 101.22 & 1.03 & 1.33 & 3.37 \\
\hline
\end{tabular}

Note: Different letters indicate significant differences based on LSD test at $5 \%$ probability level; ${ }^{* * *}$, and ns indicate significant differences at $0.05 \%, 0.01 \%$ and not significant, respectively.

\section{Seedling Growth}

The ANOVA showed no significant relationship of seed colour on seedling height, total leaf area and seedling biomass. On the other hand, data collection time recorded a significant effect on all the parameters evaluated.

Seedling height. At the end of the pre-nursery stage (three months after sowing), the plant height ranged from $31.3 \mathrm{~cm}$ (white seed) to $33.4 \mathrm{~cm}$ (black seed). There were $49 \mathrm{~cm}$ average increment in height upon seedling transplant into the main nursery at six months after sowing, for all seed colours. At nine and 12 months after sowing, no differences were generally recorded as all the seedlings attained 82$90 \mathrm{~cm}$ and more than $140 \mathrm{~cm}$ height, respectively (Table 4).

Total leaf area. At the end of the pre-nursery stage, seedling from the black seeds recorded $276.8 \mathrm{~cm}^{2}$, followed by semi-white $\left(238.2 \mathrm{~cm}^{2}\right)$ and white seed $\left(230 \mathrm{~cm}^{2}\right)$. The value then increased more than 4 -folds at six months, ranging between 888.9 to $996.8 \mathrm{~cm}^{2}$. At 9 and 12 months after sowing, significant increment was observed, where the total leaf area recorded was between $2000 \mathrm{~cm}^{2}$ (nine months) to $4700 \mathrm{~cm}^{2}$ (12 months after sowing).

Seedling biomass. In terms of shoot dry weight, the initial dry weights at three months after sowing recorded were $3.11 \mathrm{~g}$ (black seeds), $2.34 \mathrm{~g}$ (semiwhite seeds) and $2.33 \mathrm{~g}$ (white seeds). The root dry weights were generally lower, ranged from $0.87 \mathrm{~g}$ to $1.50 \mathrm{~g}$ for all the treatments. At 12 months after sowing, more than $280 \mathrm{~g}$ of shoot and $260 \mathrm{~g}$ of root dry weights were recorded. Figure 2 shows the seedlings sampled at 12 months after sowing.

\section{Seedling Physiology}

The ANOVA showed that time (months after sowing) had a significant effect on all physiological parameters. On the other hand, seed colour showed 
TABLE 4. SEEDLING HEIGHT, TOTAL LEAF AREA, SHOOT DRY WEIGHT AND ROOT DRY WEIGHTS AT 3, 6, 9 AND 12 MONTHS AFTER SOWING

\begin{tabular}{|c|c|c|c|c|c|}
\hline Months after sowing & Seed colour & $\begin{array}{l}\text { Seedling height } \\
(\mathrm{cm})\end{array}$ & $\begin{array}{l}\text { Total leaf area } \\
\qquad\left(\mathrm{cm}^{2}\right)\end{array}$ & $\begin{array}{l}\text { Shoot dry weight } \\
\text { (g) }\end{array}$ & $\begin{array}{l}\text { Root dry weight } \\
\text { (g) }\end{array}$ \\
\hline \multirow[t]{3}{*}{3 months } & Black & $33.42 \mathrm{e}$ & $276.79 \mathrm{e}$ & $3.11 \mathrm{c}$ & $1.45 \mathrm{c}$ \\
\hline & Semi-white & $32.17 \mathrm{e}$ & $238.16 \mathrm{e}$ & $2.34 \mathrm{c}$ & $1.06 \mathrm{c}$ \\
\hline & White & $31.34 \mathrm{e}$ & $230.04 \mathrm{e}$ & $2.33 c$ & $0.87 \mathrm{c}$ \\
\hline \multirow[t]{3}{*}{6 months } & Black & $49.25 d$ & $904.16 d$ & $12.34 \mathrm{c}$ & $14.30 \mathrm{c}$ \\
\hline & Semi-white & $49.00 \mathrm{~d}$ & $888.98 d$ & $13.10 \mathrm{c}$ & $13.51 \mathrm{c}$ \\
\hline & White & $48.84 \mathrm{~d}$ & $996.78 d$ & $15.05 \mathrm{c}$ & $16.34 \mathrm{c}$ \\
\hline \multirow[t]{3}{*}{9 months } & Black & $82.59 c$ & $2107.20 c$ & $50.32 b$ & \\
\hline & Semi-white & $90.84 b$ & $2003.90 c$ & $54.72 b$ & \\
\hline & White & $89.75 b$ & $2162.40 \mathrm{c}$ & $63.51 b$ & $6.49 b$ \\
\hline \multirow[t]{3}{*}{12 months } & Black & $142.09 a$ & $4368.70 b$ & $413.42 \mathrm{a}$ & $281.50 a$ \\
\hline & Semi-white & $140.75 a$ & $4652.40 a$ & 371.33 & $260.42 a$ \\
\hline & White & $148.25 a$ & $4671.90 a$ & $381.00 \mathrm{a}$ & $299.75 a$ \\
\hline Source of variation & df & \multicolumn{4}{|c|}{ Mean square (MS) } \\
\hline Block & 3 & $73.360 \mathrm{~ns}$ & $490860.4^{*}$ & $703.84 \mathrm{~ns}$ & $181.60 \mathrm{~ns}$ \\
\hline Seed colour (SC) & 2 & $33.53 n s$ & 128 230.50ns & $642.81 \mathrm{~ns}$ & $1588.47 \mathrm{~ns}$ \\
\hline Time (T) & 3 & $95031.88^{* *}$ & $129486248.50^{\star *}$ & $662563.95^{* *}$ & $630497.02^{* *}$ \\
\hline $\mathrm{SC} \times \mathrm{T}$ & 6 & $74.06 \mathrm{~ns}$ & $114406.80 \mathrm{~ns}$ & $1424.38 n s$ & $707.57 \mathrm{~ns}$ \\
\hline Error & 129 & 55.15 & 93522.90 & 1452.43 & 572.30 \\
\hline
\end{tabular}

Note: Different letters indicate significant differences based on LSD test at $5 \%$ probability level; ${ }^{* * *}$, and ns indicate significant differences at $0.05 \%, 0.01 \%$ and not significant, respectively.
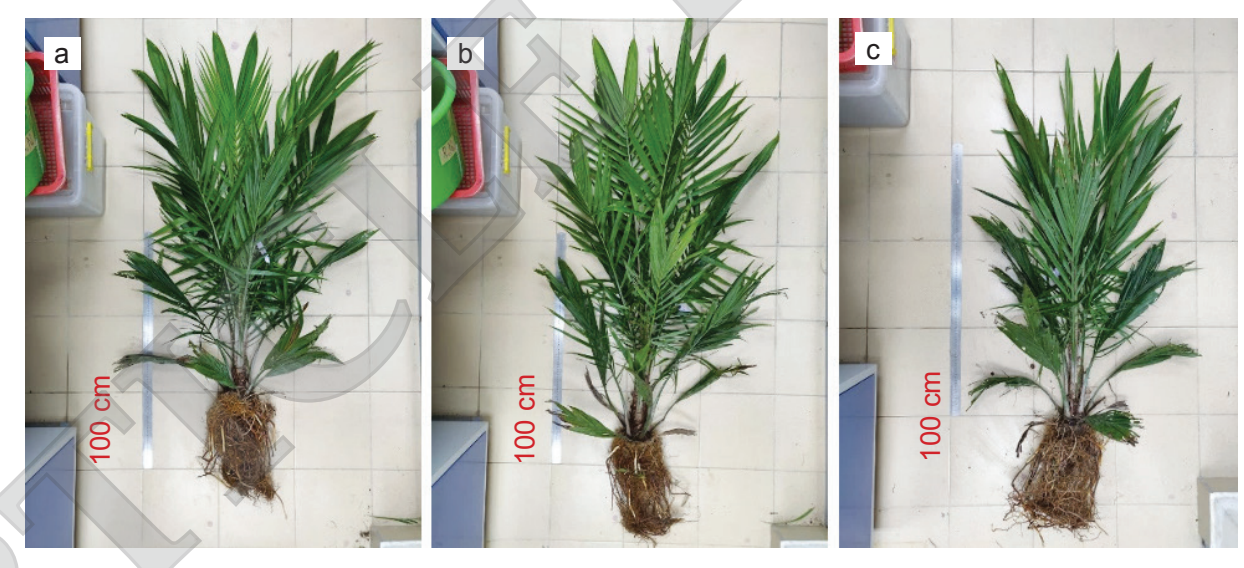

Figure 2. Oil palm seedlings from (a) black, (b) semi-white and (c) white seeds at 12 months after sowing.

no significant relationship. Net photosynthesis of black, semi-white and white seedlings ranged from 5.3 to $8.8 \mu \mathrm{mol} \mathrm{CO}_{2} \mathrm{~m}^{-2} \mathrm{~s}^{-1}$ at three months after sowing. After three months in the main nursery, the value significantly increased with semi-white seed recorded highest net photosynthesis of $18.9 \mu \mathrm{mol}$ $\mathrm{CO}_{2} \mathrm{~m}^{-2} \mathrm{~s}^{-1}$, followed by white seed $(16.87 \mu \mathrm{mol} \mathrm{CO} 2$ $\left.\mathrm{m}^{-2} \mathrm{~s}^{-1}\right)$ and black seed $\left(14.16 \mu \mathrm{mol} \mathrm{CO} \mathrm{Cm}^{-2} \mathrm{~s}^{-1}\right)$. From 9 to 12 months after sowing, the value fluctuates within 12.87-18.13 $\mu \mathrm{mol} \mathrm{CO} \mathrm{Cm}^{-2} \mathrm{~s}^{-1}$ range (Table 5).

Other physiological parameters including stomatal conductance, intercellular concentration, and transpiration rate indicated some variation among different seed types and at different stages of nursery.

\section{DISCUSSION}

Germination test conducted clearly showed 79\%$84 \%$ final germination percentage and 13-15 days mean germination time were attained, with no significant differences among the seed colours. Previous studies on other crops have shown association of seed colour with seed germinability. In most cases, the lighter coloured seeds were linked 
TABLE 5. NET PHOTOSYNTHESIS, STOMATAL CONDUCTANCE, INTERCELLULAR CONCENTRATION AND TRANSPIRATION RATE FOR BLACK, SEMI-WHITE AND WHITE SEEDS

\begin{tabular}{|c|c|c|c|c|c|}
\hline Months after sowing & Seed type & $\begin{array}{l}\text { Net photosynthesis } \\
\left(\mu \mathrm{mol} \mathrm{CO} \mathrm{m}^{2} \mathrm{~s}^{-1}\right)\end{array}$ & $\begin{array}{c}\text { Stomatal } \\
\text { conductance } \\
\left(\mathrm{mol} \mathrm{H}_{2} \mathrm{O} \mathrm{m}^{-2} \mathrm{~s}^{-1}\right)\end{array}$ & 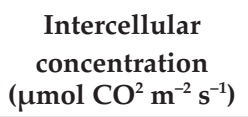 & $\begin{array}{l}\text { Transpiration rate } \\
\left(\mathrm{mmol} \mathrm{H}_{2} \mathrm{O} \mathrm{m}^{-2} \mathrm{~s}^{-1}\right)\end{array}$ \\
\hline \multirow[t]{3}{*}{3} & Black & $8.86 \mathrm{e}$ & $0.13 \mathrm{~cd}$ & 260.52abcd & $1.06 \mathrm{~cd}$ \\
\hline & Semi-white & $5.25 \mathrm{e}$ & $0.08 \mathrm{~d}$ & $227.65 b c d$ & $0.73 \mathrm{~d}$ \\
\hline & White & $5.37 \mathrm{e}$ & $0.10 \mathrm{~d}$ & $249.54 b c d$ & $0.84 \mathrm{~cd}$ \\
\hline \multirow[t]{3}{*}{6} & Black & $14.16 \mathrm{~cd}$ & $0.15 \mathrm{abcd}$ & $223.44 \mathrm{~cd}$ & $2.00 \mathrm{bcd}$ \\
\hline & Semi-White & $18.96 a$ & $0.24 \mathrm{ab}$ & $213.16 \mathrm{~d}$ & $2.95 \mathrm{ab}$ \\
\hline & White & $16.86 \mathrm{abc}$ & $0.25 \mathrm{a}$ & $237.05 d$ & $.94 \mathrm{ab}$ \\
\hline \multirow[t]{3}{*}{9} & Black & $12.87 \mathrm{~d}$ & $0.14 \mathrm{bcd}$ & $213.05 a$ & 43 \\
\hline & Semi-white & $13.87 \mathrm{~cd}$ & $0.20 \mathrm{abc}$ & $245.70 \mathrm{bcd}$ & $3.06 \mathrm{ab}$ \\
\hline & White & $13.56 \mathrm{~cd}$ & $0.22 \mathrm{abc}$ & $248.00 \mathrm{bcd}$ & $3.40 \mathrm{a}$ \\
\hline \multirow[t]{3}{*}{12} & Black & $17.02 \mathrm{abc}$ & $0.15 \mathrm{abcd}$ & $304.50 \mathrm{abc}$ & $3.20 \mathrm{ab}$ \\
\hline & Semi-white & $18.12 \mathrm{ab}$ & $0.22 \mathrm{abc}$ & 309.89ab & $2.87 \mathrm{ab}$ \\
\hline & White & $14.97 \mathrm{bcd}$ & $0.16 \mathrm{abcd}$ & $333.13 a$ & $2.10 \mathrm{abc}$ \\
\hline Source of variation & df & \multicolumn{4}{|c|}{ Mean square (MS) } \\
\hline Block & 3 & $20.55 \mathrm{~ns}$ & $0.01 \mathrm{~ns}$ & $2687.69 \mathrm{~ns}$ & $4.13 \mathrm{~ns}$ \\
\hline Seed colour (SC) & 2 & $7.49 \mathrm{~ns}$ & $0.01 \mathrm{~ns}$ & $1018.33 n s$ & $0.21 \mathrm{~ns}$ \\
\hline Time $(\mathrm{T})$ & 3 & $276.98^{*}$ & $0.03^{*}$ & 2 4071.73* & $11.03^{*}$ \\
\hline $\mathrm{SC} \times \mathrm{T}$ & 6 & $14.56 \mathrm{~ns}$ & $0.01 \mathrm{~ns}$ & $1069.56 \mathrm{~ns}$ & $1.12 \mathrm{~ns}$ \\
\hline Error & 33 & 6.35 & 0.01 & 2884.50 & 0.55 \\
\hline
\end{tabular}

Note: Different letters indicate significant differences based on LSD test at $5 \%$ probability level. ${ }^{* * *}$, and ns indicate significant differences at $0.05 \%, 0.01 \%$ and not significant, respectively.

with being immature, with lower germination percentage and vigour (Mavi, 2010; Zhang et al., 2013). This could be the reason on the consumer preference towards darker coloured oil palm seeds, and why seed producers discarded the white seeds. The association between colour and germinability is linked to seed water permeability. Powell et al. (1986) suggested that lighter coloured seeds such as white seeds imbibed water more rapidly due to higher seed coat disintegration with the cotyledons which in turn increases germination. Similarly, it was reported that dark coloured seed coat of Panicum miliaceum species were thicker, imbibed less water, thus, germinated slower (Khan et al., 1997). In contrast, dark seeds of Brassica napus showed significantly higher germination percentage and speed (Zhang et al., 2013). From the seed moisture content evaluation, oil palm white seeds showed nearly $7 \%$ higher moisture level as compared to the black seed. Seed moisture content is one of the most important aspect of development, and it is known that underdeveloped seeds generally have higher moisture level with lower capacity to germinate (Lima et al., 2012). For example, Mavi (2010) reported that light-yellow watermelon seed was found to have lower moisture content, with $40 \%$ lower emergence percentage as compared to dark brown coloured seed. Similarly, Xu et al. (2016) suggested that white seed of Zostera marina $\mathrm{L}$ were underdeveloped with smaller seed sizes and $11 \%$ higher moisture in comparison with the black seed. However, in oil palm seed, despite the prominent difference in moisture; seed capacity to germinate was not affected. Thus, in this scenario, the difference may be due to higher endocarp moisture retention of the white seed, which could possibly be linked to the endocarp composition and was not a measure of seed maturity.

According to the nursery evaluation, oil palm seedlings showed similar growth pattern among different seed colours. In general, there was 4 to 6-fold increase in terms of overall biomass production at every three months data collection interval. Most studies conducted previously, associated seed colour with other characteristics, mainly the water permeability. Higher water permeability enables faster germination and earlier seedling establishment which allows for competitive advantage for a vigorous initial seedling growth (Powell et al., 1986; Mohamed-Yasseen et al., 1994). Stringam et al. (1974) reported that there was a correlation between colour, seed coat thickness and seedling growth in Brassica rapa. Velijevic et al. (2017) also revealed that bright coloured Trifolium pratense seeds showed higher seedling vigour and growth in comparison with darker coloured seeds. The effect 
of seed colour was even linked to yield components such as oil production. Bagheri et al. (2013) reported that genotypes with reddish-brown seed coat of Brassica rapa had higher oil content in comparison to the yellow-seeded genotypes. Similar finding from Zhang et al. (2013) reported that darker Brassica napus seeds resulted in higher seedling emergence percentage, vigour, shoot and root length, as well as the seed oil content. Interestingly, within the first three months of the nursery evaluation (end of pre-nursery), black seed did show higher growth (such as mean root/ shoot dry weight and total leaf area as shown in Table 4), if we analyse the data based on single data collection point (instead of using a pooled LSD-value). Based on the seed characteristics evaluation (Table 2), it was evident that black seeds were generally larger in size and weight, as compared to white seeds. Studies have shown previously that seed size plays an important role in early seedling establishment. Larger seed size can be associated with larger endosperm reserve. Finch-Savage and Bassel (2016) suggested that differences in lipid reserve mobilisation rate may contribute to the early seedling establishment after germination commencement. In the case of oil palm seedling, the larger size of black seed may attribute to the more vigorous growth within the first three months, as the seedling utilised more endosperm reserve during initial establishment. It is known that the main role of endosperm is as a primary means of nutrient supply as well as the regulator of embryonic growth during seed development and germination, along with other diverse functions (Copeland and McDonald, 2001; Yan et al., 2014). However, with further seedling growth, and the utilisation of available nutrients from the soil, no differences were observed.

There was limited literature that associate seed colour with the physiological performance on developing seedlings. Most of the evaluation were conducted until germination stage and early seedling vigour assessment as discussed above. However, the performance can still be assessed according to the main physiological component of seedling growth particularly the leaf photosynthetic capacity, along with other contributing factors including chlorophyll contents, stomatal conductance, transpiration rate as well as the intercellular $\mathrm{CO}_{2}$ concentration. The leaf which serves as main vegetative plant part to capture light was considered as highly plastic, making it the most evaluated components in determining plant physiological function as well as stress indicator (Dickison, 2000). In this study, the net photosynthesis values were similar among different seed colours but varies with time of data collection. Initially, the values were between 5.3 to $8.8 \mu \mathrm{mol} \mathrm{CO} \mathrm{CO}_{2} \mathrm{~m}^{-1}$ (three months) and then increased up to $18.13 \mu \mathrm{mol}$ $\mathrm{CO}_{2} \mathrm{~m}^{-2} \mathrm{~s}^{-1}$ towards the end of the evaluation period.
Ibrahim et al. (2010) reported that net photosynthesis of seven months old oil palm seedlings exposed to normal $400 \mathrm{ppm}$ atmospheric $\mathrm{CO}_{2}$ level were between 15 to $20 \mu \mathrm{mol} \mathrm{CO}_{2} \mathrm{~m}^{-2} \mathrm{~s}^{-1}$. On the other hand, lower net photosynthesis ranging from 4 to 9 $\mu \mathrm{mol} \mathrm{CO} \mathrm{Cm}^{-2} \mathrm{~s}^{-1}$ was shown by 12 months old sago palm (Azhar et al., 2018) and young macaw palm seedlings (Dias et al., 2018). By comparing these values from Ibrahim et al. (2010) and Azhar et al. (2018), it is evident that all the seed colour produces seedlings that have normal photosynthetic capacity at both pre-nursery and main nursery stages. The increasing net photosynthesis value from three months to the remaining nine months of nursery evaluation indicates higher energy requirement of the growing seedlings (Bravdo, 1971). These differences in photosynthesis also explained the variation observed throughout the 12 months evaluation period for other physiological parameters (transpiration rate, stomatal conductance, and intercellular $\mathrm{CO}_{2}$ concentration) which are known to influence the overall plant photosynthetic capacity. In juvenile oil palm seedlings, the frond leaflets are the main site of gas exchange such as $\mathrm{CO}_{2}$, water vapour and oxygen as well as photosynthesis. The gas exchange is primarily regulated by the stomata on both the abaxial and adaxial of the leaf surfaces. During periods with high photosynthetic activities, the oxygen concentration will increase which in turn decreases the intercellular $\mathrm{CO}_{2}$ concentration. This will affect the concentration gradients of these gasses, thus, influence the diffusion rates (Haniff, 2006).

In this study, it was found that white seed occurrence is more prominent in the base section of the spikelet within the bunch. This could be due to less pigmentation from lower sunlight exposure for seed that were located at the base region of the spikelet. For the same reason, slower rate of desiccation was observed for white seeds since as it is well protected underneath seeds located at the apex of the spikelets. Therefore, based on these findings, seed colour in oil palm could be associated with the natural pigmentation during developmental process. In the case of rapeseed, water uptake and tolerance to excessive water was linked to seed coat colour and melanin pigmentation. It was shown that black and red seed have higher melanin pigment as compared to yellow and lighter coloured seeds (Zhang et al., 2006; Zhang et al., 2008). The seed morphological features were highly influenced by environmental stimuli which leads to changes in seed composition (Lacey, 1998; Senda et al., 2004). Therefore, it is possible that oil palm seed colour will change from white to black with maturity and upon exposure to environmental stimuli. The possibility of genetic influence towards seed colour was previously shown in sweet clover (Melilotus alba Desr), where it was found that green 
and brown colour pigmentation on the seed coat were controlled by $\mathrm{Y} / \mathrm{y}$ and $\mathrm{C} / \mathrm{c}$ alleles, respectively (Gorz et al., 1975). Similarly, Vandenberg and Slinkard (1990) reported both grey and tan ground colours in lentils were controlled by two dominant genes in an independent locus. In oil palm seeds, the genetic effect was reported only for exocarp colour, where virescens (VIR) gene was known to be responsible for the VIR trait (Singh et al., 2014). In this study, there was no evident on genetic influence towards seed colour, since only similar commercial variety of DxP CALIX 600 was evaluated. However, it is possible that different progenies used by seed producers could also affect the seed colour during development process. In general, based on the germination data along with nursery evaluation, it is evident that the quality of white seeds in terms of germination and seedling characteristics are equal to the black seeds. Therefore, white seeds no longer need to be discarded in commercial DxP seed production. Nevertheless, a follow up research on the performance of the plants in the field may benefit this long-term crop in relation to yield and oil content. The main challenge to seed producers would be to spread awareness to buyers and consumers regarding this matter.

\section{CONCLUSION}

This is the first study conducted on the performance of commercial oil palm DxP seeds based on seed colour in terms of ability to germinate and subsequent seedling performance at the nursery stages. The results show that seed colour differs in oil palm bunch due to spatial developmental process, which causes white and less pigmented seed at the base region of the spikelet. It was found that all seed types recorded 79\%-84\% normal germination within 13-15 days. In terms of seedling performance, black seeds show higher overall biomass and other growth parameters only for the first three months. However, at 6, 9 and 12 months, all the seed colours showed similar morphological development. The physiological evaluation also indicated that oil palm seed produces physiologically similar and normal seedlings, regardless of the colour. Overall, oil palm seed colour is not linked to germination capacity and seedling performance prior to field planting.

\section{ACKNOWLEDGEMENT}

Highest appreciation to Sime Darby Research Sdn. Bhd., for providing us with the materials, facilities and technical assistance throughout this study. We also thank the Ministry of Higher Education Malaysia and Universiti Putra Malaysia for the financial support through SLAB scholarship and Junior Academic Scheme during this study period.

\section{REFERENCES}

Azhar, A; Makihara, D; Naito, Hand Ehara, H (2018). Photosynthesis of sago palm (Metroxylon sagu Rottb.) seedling at different air temperatures. Agriculture, 8: 1-10. DOI: 10.3390 / agriculture8010004.

Bagheri, H; Pino-del-Carpio, D; Hanhart, C; Bonnema, G; Keurentjes, J and Aarts, M G M (2013). Identification of seed-related QTL in Brassica rapa. Span. J. Agric. Res., 11(4): 1085-1093. DOI: 10.5424/ sjar/2013114-4160.

Bravdo, B (1971). Carbon dioxide compensation points of leaves and stems and their relation to net photosynthesis. Plant Physiol., 48(5): 607-612.

Copeland, L and McDonald, M (2001). Seed dormancy. Principles of Seed Science and Technology. Fourth edition, Springer Science and Business Media, New York. Clutter. p. 140-164. DOI: 10.1007/978-14615-1619-4.

Corley, R H V and Tinker, P B (2015). The Oil Palm. Fifth edition. Wiley Blackwell Science. Oxford, United Kingdom.

Corley, R H V (2009). How much palm oil do we need? Environ. Sci. Policy, 12:134-139. DOI: 10.1016/j. envsci.2008.10.011.

Department of Standards Malaysia (2005). Oil palm seeds for commercial planting - specification (Third Revision), Malaysian Standard MS 157: 2005. Standards and Industrial Research Institute of Malaysia Berhad, Selangor.

Dias, A N; Siqueira-Silva, A I; Souza, J P; Kuki, K N and Pereira, E G (2018). Acclimation responses of macaw palm seedlings to contrasting light environments. Sci. Rep., 8: 15300. DOI: 10.1038/ s41598-018-33553-1.

Dickison, W C (2000). Integrative Plant Anatomy. Academic Press, San Diego.

Finch-Savage, W E and Bassel, G W (2016). Seed vigour and crop establishment: Extending performance beyond adaptation. J. Exp. Bot., 67: 567-591. DOI: $10.1093 / j x b / e r v 490$.

Gorz, H J; Specht, J E and Haskins, F A (1975). Inheritance of seed and seedling colour in sweet clover. Crop Sci., 15: 235-238. DOI: 10.2135/ cropsci19 75.0011183X001500020028x. 
Haniff, M H (2006). Gas exchange of excised oil palm (Elaeis guineensis) fronds. Asian J. Plant Sci., 5(1): 9-13. DOI: 10.3923 / ajps.2006.9.13.

Ibrahim, M H; Jaafar, H Z E; Harun, M H and Yusop, M R (2010). Changes in growth and photosynthetic patterns of oil palm (Elaeis guineensis Jacq.) seedlings exposed to short-term $\mathrm{CO}_{2}$ enrichment in a closed top chamber. Acta Physiol. Plant., 32(2): 305-313.

International Seed Testing Association (2016). International Rules for Seed Testing. Bassersdorf, CH-Switzerland.

Khan, M; Cavers, P B; Kane, M and Thompson, K (1997). Role of the pigmented seed coat of proso millet (Panicum miliaceum L.) in imbibition, germination and seed persistence. Seed Sci. Res., 7(1): 21-26.

Kushairi, A; Tarmizi, A H; Zamzuri, I; Ong-Abdullah, M; Samsul Kamal, R; Ooi, S E and Rajanaidu, N (2010). Production, performance and advances in oil palm tissue culture. International Seminar on Advances in Oil Palm Tissue Culture. International Society for Oil Palm Breeders (ISOPB). 29 May 2010. Yogyakarta, Indonesia.

Lacey, E P (1998). What is an adaptive environmentally induced parental effect? Maternal Effects as Adaptations (Mousseau, T A and Fox, C W eds.). Oxford University Press, Oxford, United Kingdom. p. 54-66.

Lima, C B; Bruno, R L A; Silva, K R G; Pacheco, M V; Alves, E U and Andrade, A P (2012). Physiological maturity of fruits and seeds of Poincianella pyramidalis (Tul.) L.P. Queiroz. Rev. Bras. Sementes, 34(2): 231-240. DOI: $10.1590 /$ S0101-31222012000200007.

Malaysian Palm Oil Board (2020). Demand of germinated seed. http: / / bepi.mpob.gov.my/index. php/en/, accessed on 20 March 2020.

Malaysian Palm Oil Council (2018). Malaysian Palm Oil Council Official website. http: / / www.mpoc.org. my, accessed on 14 August 2018.

Mavi, K (2010). The relationship between seed coat colour and seed quality in watermelon Crimson sweet. Hort. Sci., 37(2): 62-69.

Mohamed-Yasseen, Y; Barringer, S A; Splittstoesser, W E and Costanza, S (1994). The role of seed coats in seed viability. Botanical Review, 60: 426-439.

Padilla, F M and Pugnaire, F I (2007). Rooting depth and soil moisture control Mediterranean woody seedling survival during drought. Funct. Ecol., 21: 489-495.
Powell, A A; Oliveira, M A and Matthews, S (1986). The role of imbibition damage in determining the vigour of white and coloured seed lots of dwarf French beans (Phaseolus vulgaris). J. Exp. Bot., 37(5): 716-722.

Sime Darby Seeds and Agricultural Services (2020). DxP Seed Production Protocol, Standard Operation Procedures. Sime Darby Research, Malaysia.

Senda, M; Masuta, C; Ohnishi, S; Goto, K; Kasai, A; Sano, T; Hong, J S and MacFarlane, S (2004). Patterning of virus-infected Glycine max seed coat is associated with suppression of endogenous silencing of chalcone synthase genes. Plant Cell, 16(4): 807-818.

Singh, R; Low, E T; Ooi, L C; Ong-Abdullah, M; Nookiah, R; Ting, N C; Marjuni, M; Chan, P L; Ithnin, M; Manaf, M A; Nagappan, J; Chan, K L; Rosli, R; Halim, M A; Azizi, N; Budiman, M A; Lakey, N; Bacher, B; Van-Brunt, A; Wang, C; Hogan, M; He, D; MacDonald, J D; Smith, S W; Ordway, J M; Martienssen, R A and Sambanthamurthi, R (2014). The oil palm virescens gene controls fruit colour and encodes a R2R3-MYB. Nat. Commun., 5: 4106. DOI:10.1038/ncomms5106.

Stringam, G R; Mcgregor, D and Pawlowski, S H (1974). Chemical and morphological characteristics associated with seed coat colour in rapeseed. Proc. of the $4^{\text {th }}$ International Rapeseed Congress. Giessen, Germany. p. 99-108.

Turner, P D and Gillbanks, R A (2003). Oil palm cultivation and management. The Incorporared Society of Planters, Kuala Lumpur.

USDA (2020). Oilseeds: World Markets and Trades. Foreign Agricultural Service. United States Department of Agriculture. https://apps.fas.usda. gov/psdonline/ circulars / oilseeds.pdf.

Vandenberg, A and Slinkard, A E (1990). Genetics of seed coat color and pattern in lentil. J. Hered., 81 (6): 484-488.

Velijevic, N; Štrbanović, R; Poštić, D; Stanisavljevic, R and Djukanovic, L (2017). Effects of seed coat colour on the seed quality and initial seedling growth of red clover cultivars (Trifolium pratense). J. Processing and Energy in Agriculture, 21: 174-177. DOI: 10.5937/ JPEA1703174V.

Xu, S; Zhou, Y; Wang, P; Wang, F; Zhang, X and $\mathrm{Gu}, \mathrm{R}$ (2016). Salinity and temperature significantly influence seed germination, seedling establishment and seedling growth of eelgrass Zostera marina L. PeerJ, 4: e2697. DOI: 10.7717/ peerj.2697. 
Yan, D; Duermeyer, L; Leoveanu, C and Nambara, E (2014). The functions of the endosperm during seed germination. Plant Cell Physiol., 55(9): 1521-1533. DOI: $10.1093 /$ pcp/pcu089.

Zhang, X K; Chen, J; Chen, L; Wang, H Z and Li, J N (2008). Imbibition behaviour and flooding tolerance of rapeseed seed (Brassica napus L.) with different testa color. Genet. Resour. Crop Evol., 55: 1175-1184.
Zhang, X K; Yang, G T; Chen, L; Yin, J M; Tang, Z and Li, J N (2006). Physiological differences between yellow-seeded and black seeded rapeseed (Brassica napus L.) with different testa characteristics during artificial ageing. Seed Sci. Technol., 34(2): 373-381.

Zhang, J; Ying, C; Liyan, Z; Yilin, W; Jing, L; Guijun, Y and Liyong, H (2013). Seed coat color determines seed germination, seedling growth and seed composition of canola (Brassica napus). Int. J. Agric. Biol., 15(3): 535-540. 